\section{Thomas Anton}

Thomas Anton passed away on June 6, 2006, following a battle with cancer. Professor Anton was the A. Alfred Taubman Professor of Public Policy and American Institutions, professor of Political Science, and founding director of the Taubman Center for Public Policy at Brown University. He served as director of the Taubman Center from 1984 to 2000.

Anton was born September 28, 1934, in Worcester, Massachusetts. He graduated magna cum laude with a bachelor's degree from Clark University in 1956 and earned his Ph.D. from Princeton University in 1961. He served as a doctoral fellow and lecturer at the University of Pennsylvania from 1959 to 1961 . He was an assistant professor of government and public affairs at the University of Illinois from 1961 to 1967 . From 1967 to 1983 , he was an associate and full professor of political science at the University of Michigan. During his time at Michigan, he was acting director of the Institute of Public Policy Studies from 1973 to 1974 and director of the Intergovernmental Fiscal Analysis Project from 1978 to 1983.

Anton was an internationally renowned political scientist whose pathbreaking studies of federalism and public policy won many prestigious awards. He was the author or co-author of 14 books and monographs and over 50 articles in scholarly journals. Among his most important books were The Politics of State Expenditures in Illinois (University of Illinois Press, 1975), Governing Greater Stockholm (University of California Press, 1975), Federal Aid to Detroit (Brookings Institution Press, 1983), and American Federalism and Public Policy: How the System Works (Random House, 1989). He was a past editor of the journal Policy Sciences.

His book, American Federalism and Public Policy, won the 1989 Gladys M. Kammerer Award presented by the American Political Science Association "for the best political science publication in the field of U.S. national policy." The book presented a "real-politic" approach to American federalism and described how leaders use "benefit coalitions" to build support in fragmented political systems.

Anton was the recipient of many grants and fellowships. Among his grant sponsors were the Ford Foundation, the Bydale Foundation, and the National Sci- ence Foundation. Furthermore, he was the recipient of the John F. Kennedy Fellowship from the government of Sweden, the American Philosophical Society Fellowship, the Rackham Research Fellowship, a Fulbright Fellowship, and a John Simon Guggenheim Memorial Fellowship.

In 2000, he was selected to receive the Distinguished Federalism Scholar award by the American Political Science Association. The award honored Anton as a scholar who made significant contributions to the field of federalism. He was an early leader in the compilation of large data systems to track the flow of funds among national, state, and local governments and was one of the earliest scholars to utilize geographic displays of such data to reveal patterns of federal policy.

While at Brown University, Anton was active in a wide range of public and community service. He served as chair of the Board of Commissioners of the Providence Housing Authority and as founder-director of The Providence Plan, a non-profit organization dedicated to community revitalization. In 1992, he received an individual recognition award for his contributions to housing policy. He served the University as dean of the Faculty in 1990-1991. In 1991, he was elected a trustee at Clark University, and in 1995, he became vice-chair of the Clark University Board of Trustees.

Thomas Anton is survived by his wife Barbara of Orleans, Massachusetts, and three children: Lynn Allen and Thomas R. Anton of Michigan and Leslie Anton of Brewster, Massachusetts. He had four grandchildren and two greatgrandchildren. Contributions to honor his memory can be made to the Thomas J. Anton Fund at the Taubman Center for Public Policy, 67 George Street, Brown University, Providence, RI 02912-1977.

Darrell West Terence Hopmann Brown University

\section{Gottfried Dietze}

On Tuesday, June 20th, the department of political science learned of the death of Professor Gottfried Dietze, a member of the faculty at Johns Hopkins University since 1954. Dietze was born in 1922 in Homburg, Germany, and studied under Carl Friedrich at Harvard University and Alpheus Mason at
Princeton University. His most widely read publication was The Federalist, originally published by Johns Hopkins University Press in 1960. Dietze died at his home in Washington, D.C.

\section{Jane Bennett \\ Johns Hopkins University}

\section{Leon D. Epstein}

Leon D. Epstein died on Tuesday, August 1, 2006, as the result of injuries suffered in a fall at home two days earlier. He was a scholar of international repute in the realm of political parties, a central figure in the postwar re-creation of the department of political science at the University of Wisconsin, Madison, as well as a former president of the American Political Science Association and a fellow of the American Academy of Arts and Sciences.

Leon was born on May 29, 1919, in Milwaukee, Wisconsin, though he grew up in Beaver Dam, a town where, as he wryly noted, the great enemy of the locals in his youth was not the rising fascist or communist states of the wider world but the Wisconsin DNR, the Department of Natural Resources, known locally as "damned near Russian." $\mathrm{He}$ came to Madison, to the University of Wisconsin, in 1936 to begin his undergraduate career, a career that would be closely entwined with that university ever after. He received a B.A. from UWMadison in economics in 1940, an M.A. in economics in 1941, and then left for military service.

Stationed in Britain for two of those years, Leon used any spare time to immerse himself in the details of British politics, managing to cap his war-time service with a term at Oxford. Returning to the U.S., he enrolled for a Ph.D. in political science at the University of Chicago, obtained in 1948. After Chicago, he accepted a one-year teaching post at the University of Oregon for 1947-1948, returning to the department of political science at the University of Wisconsin at Madison the following year. He would remain on the Madison faculty until his retirement in 1988. While still at Chicago, he met and married Shirley (Galewitz) Epstein, to whose care he was devoted in his later years and who preceded him in death in 2001.

The official history of the department of political science at UW-Madison (2006) notes that "the resurrection of 